\title{
The Use of Bedside Ultrasound for Gallstone Disease Care within a Community-based Emergency Department: A Confirmation Bias
}

\author{
Karin H Gunther, D.O., MSE ${ }^{1}$ @, Joshua Smith, D.O. ${ }^{2}$ Judith Boura, M.S. ${ }^{3}$ Andrew Sherman, D.O. ${ }^{4}$, David Siegel, D.O., \\ FACOS, FACS ${ }^{5}$ \\ ${ }^{1}$ General Surgery, Ascension Macomb-Oakland Hospital, ${ }^{2}$ Internal Medicine, Beaumont Hospital, ${ }^{3}$ Research, Ascension Macomb, 4 William \\ Beaumont Army Medical Center, ${ }^{5}$ General Surgery, Ascension Macomb \\ Keywords: gallbladder disease, point-of-care ultrasound, bedside ultrasound, emergency department \\ https://doi.org/10.51894/001c.18182
}

\section{Spartan Medical Research Journal}

Vol. 6, Issue 1, 2021

\section{INTRODUCTION}

Traditional evaluation for suspicion of gallstone or gallbladder-related disease includes evaluation with a formal technician-performed ultrasound. However, the use of point-of-care bedside ultrasounds (Bedside US) has been shown to be a viable alternative for the diagnosis of gallstones and gallbladder-related diseases. Purpose Statement: The purpose of this study was to evaluate the impact of Bedside US use in gallbladder evaluation on key patient care outcomes within our community-based emergency department setting.

\section{METHODS}

This retrospective study compared the use of no ultrasound (No US), a formal technician performed ultrasound (Tech US) and Bedside US for gallstone and gallbladder related diseases within a community hospital emergency department between January 1, 2015 and January 1, 2018. Initial vitals, lab work, patient socio-demographics, medical history, emergency department length of stay in hours and disposition were reviewed.

\section{RESULTS}

Of a total $\mathrm{N}=449$ patients included, patients who received a Bedside US had the fewest computerized tomography scans (No US $62 \%$ vs. Tech US $29 \%$ vs. Bedside US $16 \%$; $<$ < 0.0001 ), the shortest median emergency department length of stay (No US 4.5 days vs. Tech US 5.0 days vs. Bedside US 3.0 days; $\mathrm{p}<0.0001$ ), and were more likely to be discharged home (No US $41 \%$ vs. Tech US $55 \%$ vs. Bedside US $81 \%$; $\mathrm{p}=0.0006$ ) compared to those that received no ultrasound or a formal ultrasound. Patients who received a Bedside US also had the statistically significant highest incidence of prior cholelithiasis (No US $29.4 \%$ vs Tech US $14.3 \%$ vs. Bedside US $31.3 \%$; $p=0.001$ ) and lowest total median bilirubin levels (No US 0.5 vs. Tech US 0.5 vs. Bedside US $0.3 ; p=0.016$ ) when compared to the other two groups.

\section{CONCLUSIONS}

Although there was a confirmation bias, these study results indicate that point-of-care bedside ultrasound could be a viable alternative for gallstones and gallbladder-related diseases with benefits of use in a community hospital setting.

\section{INTRODUCTION}

Gallstone disease is the most common and costly disorder affecting the body's biliary (i.e., relating to bile or bile ducts) system. ${ }^{1-3}$ Gallstones are generated from an imbalance of bile salts, cholesterol and phospholipids. ${ }^{2-5}$ Risk factors for developing gallstone disease include female gender, age, obesity, diet, insulin-resistance, and rapid weight loss. ${ }^{2,5-13}$ Typically, patients first present to emergency departments (ED) with symptoms of right upper quadrant or epigastric abdominal pain, nausea, vomiting and/or jaun- dice. ${ }^{2,13-15}$

Diagnosis and evaluation for gallstone related disease begins with a complete physical exam, laboratory evaluation, and imaging with initial imaging modality of choice being an abdominal ultrasound. ${ }^{15,16}$ Other imaging modalities, such as computed tomography (CT) and magnetic resonance imaging (MRI), are not generally recommended as initial imaging exams. However, these modalities have proven beneficial when ultrasound results are equivocal. ${ }^{17,18}$

In smaller community hospital ED an ultrasound techni- 
cian is not always available throughout the day to assess patients. ${ }^{19}$ A potential solution to this dilemma of community institutions lacking formal ultrasound technician staffing is an informal screening point-of-care bedside ultrasound (Beside US), which can be performed by ED physicians. ${ }^{19,20}$ The use of Bedside US has been proven beneficial in the evaluation of several other thoracic and abdominal diseases in a variety of clinical settings. ${ }^{20-24}$ In gallbladder diseases, Bedside US has been shown to be $55 \%$ to $95 \%$ sensitive and $82 \%$ to $100 \%$ specific for cholelithiasis (i.e., the formation of gallstones) and acute cholecystitis, as well as decreased ED length of stay. ${ }^{25-34}$

In rare deadly biliary diseases, such as emphysematous cholecystitis (i.e., acute infection of the gallbladder wall caused by bacterial gas-forming organisms such as Clostridium or Escherichia coli), Bedside US has been concluded to be useful in aiding identification and diagnosis. ${ }^{35,36}$ However, Bedside US has not been uniformly adopted in most settings despite these studies. This may be attributed to the lack of ultrasonographic training programs, technology, surgeon perception of Bedside US and the lack of high-quality prospective studies that evaluate point-of-care imaging on operative decision making in patients with cholelithiasis or cholecystitis. ${ }^{19,32,34}$

\section{PURPOSE OF STUDY}

The purpose of our study was to evaluate the impact of Bedside US use in gallbladder evaluation on key patient care outcomes within our community-based ED setting. The overall null hypothesis of the study authors was that they would be unable to identify any statistically significant health outcome differences across ultrasound sample subgroups.

\section{METHODS}

The authors conducted a retrospective electronic health record (EHR) review at a Level III trauma center ED with 33,000 annual visits for patients who presented between January 1, 2015 and January 1, 2018 with symptoms for biliary disease. International Classification of Diseases, Ninth Revision, Clinical Modification (ICD-9) and Tenth Revision, Clinical Modification (ICD-10) codes pertaining to biliary disease were used by the authors to establish the initial patient list. ${ }^{37,38}$ Data concerning patient socio-demographics (e g., age, racial affiliation, gender identification), pertinent past medical and surgical history, allergies, initial vitals and lab results, imaging studies, length of ED stay, and ED disposition were collected by first author (KG), second author (JS), and fourth author (AS) from the Cerner Millennium ${ }^{\circledR}$ EHR system. ${ }^{39}$

Sample patients included those who were: 1) 18 years and older, 2) presented to the ED for the first time with signs and symptoms of biliary disease (i.e., right upper quadrant or epigastric abdominal pain) and 3) diagnosed with an ICD-9 or ICD-10 coded biliary disorder diagnosis. A total of 449 patients identified met these sampling criteria.

Patients were then categorized into: 1) those receiving no ultrasound (No US), 2) a formal ultrasound (i.e., by an ultrasound technician from the radiology department, Tech
US) or 3) a Bedside US (i.e., as performed by an ED attending or ED resident physician). Before study data were collected, the study design had been approved by the authors' Institutional Review Board at the Ascension St. John Hospital in Detroit, Michigan.

\section{STATISTICAL ANALYSES}

Descriptive statistics were first provided by the GME biostatistician third author (JB) for all data collected. Missing data remained missing and was not replaced with substitutions or imputations. All analyses were conducted by third author (JB) using SAS for Windows ${ }^{\circledR}$ 9.4, Cary, NC. Statistical significance was interpreted observing a Coefficient Alpha of 0.05 parameter.

Categorical variables are provided as counts and percent frequencies. Categorical variables were examined between the three sample subgroups with Chi-square tests where appropriate (expected frequency > five in $80 \%$ of cells), otherwise Fisher's Exact tests were used. ${ }^{40}$ All continuous variables are reported in this paper as either means +/- the standard deviation or median and $25^{\text {th }}$ and $75^{\text {th }}$ percentiles, followed by the minimum to maximum dependent on the normality of the data. Continuous data was examined between the three groups with Kruskal-Wallis tests. ${ }^{41}$

\section{RESULTS}

Of 449 patients evaluated, there was no statistically significant difference in patient age, gender, race, BMI, allergies (i.e. iodine), history of prior bariatric surgery, or initial vital signs between patients who received No US, Tech US or Bedside US. The only statistically significant socio-demographics or medical history difference between patient ultrasound imaging groups was in history of cholelithiasis, with patients receiving a Tech US having the lowest frequency (Table 1).

Pertinent labs evaluated included white blood cell count, hemoglobin, blood urea nitrogen (BUN), creatinine, total bilirubin, aspartate aminotransferase (AST), alanine aminotransferase (ALT), alkaline phosphatase (Alk Phos), and lipase. For pertinent labs, patients having a Bedside US were found to have a lower median total bilirubin value when compared to the other two subgroups (Table 2). There were no statistically significant differences found in WBC (i.e., a key indicator for acute cholecystitis) or renal function measures (i.e., BUN and creatinine). Insufficient data were available to evaluate for direct bilirubin to determine a statistical difference.

The Bedside US sample subgroup was also found to have the lowest rate of CT imaging compared with those that did not receive an ultrasound having the highest rates of CT imaging. Patients receiving a Bedside US were also found to have decreased ED length of stay and were more likely to be discharged home than patients in the other two sample cohorts (Table 3).

\section{DISCUSSION}

The primary benefit of a Bedside US (a.k.a. point-of-care ul- 
Table 1. Sample Socio-Demographics and Medical History

\begin{tabular}{|c|c|c|c|c|}
\hline & $\begin{array}{l}\text { No Ultrasound } \\
(\mathrm{N}=235)\end{array}$ & $\begin{array}{l}\text { Formal Ultrasound } \\
(\mathrm{N}=182)\end{array}$ & $\begin{array}{l}\text { Bedside Ultrasound } \\
(\mathrm{N}=32)\end{array}$ & $\begin{array}{c}\mathrm{p}- \\
\text { value }\end{array}$ \\
\hline Age & & & & 0.13 \\
\hline Mean+/- SD (median) & $50+/-19(48)$ & $47+/-18(45)$ & $45+/-17(47)$ & \\
\hline Min to $\max$ & 19 to 101 & 19 to 95 & 18 to 91 & \\
\hline Gender Identity & & & & 0.31 \\
\hline Males & $73(31.1 \%)$ & $64(35.2 \%)$ & $7(21.9 \%)$ & \\
\hline Female & $162(68.9 \%)$ & $118(65.8 \%)$ & 25 (78.1\%) & \\
\hline Racial Affiliation & & & & 0.18 \\
\hline White & 154 (65.5\%) & $112(61.2 \%)$ & $16(50.0 \%)$ & \\
\hline Black & 44 (18.7\%) & 40 (21.9\%) & $13(40.6 \%)$ & \\
\hline Other & $7(3.0 \%)$ & $6(3.3 \%)$ & $0(0.0 \%)$ & \\
\hline Unknown & 30 (12.8\%) & 25 (13.7\%) & $3(9.4 \%)$ & \\
\hline BMI & & & & 0.47 \\
\hline Mean+/- SD (median) & $33+/-11(31)$ & $33+/-8(32)$ & $31+/-8(29)$ & \\
\hline Min to $\max$ & 17 to 87 & 17 to 74 & 18 to 53 & \\
\hline \multicolumn{5}{|l|}{ Medical History } \\
\hline Hypertension & $95 / 228(41.7 \%)$ & $55 / 178(30.9 \%)$ & $10 / 32(31.3 \%)$ & 0.067 \\
\hline Dyslipidemia & $51 / 228(22.4 \%)$ & $38 / 178(21.4 \%)$ & 6/32 (18.8\%) & 0.89 \\
\hline Diabetes Mellitus & 41/228(18.0\%) & $23 / 178(12.9 \%)$ & 6/32 (18.8\%) & 0.35 \\
\hline Obesity & $114 / 229(49.8 \%)$ & $99 / 182(54.4 \%)$ & $13 / 32(40.6 \%)$ & 0.31 \\
\hline Cholelithiasis & 68/231 (29.4\%) & $25 / 175(14.3 \%)$ & $10 / 32(31.3 \%)$ & 0.001 \\
\hline $\begin{array}{l}\text { Prior Bariatric } \\
\text { Surgery }\end{array}$ & $16 / 229(7.0 \%)$ & $11 / 178(6.2 \%)$ & $0 / 32(0.0 \%)$ & 0.31 \\
\hline lodine Allergy & 7/234 (3.0\%) & $6 / 182(3.3 \%)$ & $2 / 32(6.3 \%)$ & 0.63 \\
\hline
\end{tabular}

$\mathrm{SD}=$ standard deviation

BMI = Body Mass Index

Statistically significant values appear in bold font.

trasound) remains its use in resource-limited settings, as they provide a low-cost method to aid in diagnosis and management of many conditions. ${ }^{42}$ Our study findings support prior findings that Bedside US may be a functional alternative to Tech US in diagnosing gallbladder-related disorders. In addition, our results resembled two previous studies that Bedside US by an ED attending or ED resident is associated with decreased ED length of stay and decreased CT scan use (i.e., unnecessary radiation exposure). ${ }^{26,35}$

Unlike the studies by Blaivas et al. ${ }^{26}$ performed at a tertiary care center or Summers et al. ${ }^{32}$ which was performed at an urban hospital with an emergency US fellowship, our study was conducted at a small community hospital with results more likely to be more representative of smaller institutions where ultrasound availability may be limited and the variability of patient acuity may lead to variable physician comfort levels with Bedside US use. ${ }^{26,32}$

As expected, the characteristics of our sample parallel the typical demographics of American patients seen with cholelithiasis and gallstone-related diseases (see Table 1): female, obese (i.e., BMI > 30), and ages within the $4^{\text {th }}$ and $5^{\text {th }}$ decades of life. ${ }^{6,7,17}$ However, our study results suggest that there may be a bias associated with the use of Bedside US within our smaller community hospital.
In our study, patients who received a Bedside US were more likely to have known history of cholelithiasis (Table 1), decreased total bilirubin (Table 2), and more likely to be discharged home $(81.3 \%)$ than those that received a formal ultrasound $(55 \%)$ or no ultrasound $(40.9 \%)(p=0.0006)$ (Table 3). Thus, our sample patients chosen to have a Bedside US in our study were more likely to have classic symptomatic cholelithiasis or biliary colic presentation than those who received Tech US or NO US. This may reflect a confirmation bias, (i.e., tendency to look for confirmatory evidence to support a diagnosis) associated with the use of the Bedside US in patients presenting with classic cholelithiasis symptoms. ${ }^{43}$

This conclusion is further supported by an increased disposition to discharge these patients home found within our study (81\%) when Bedside US was used, as compared to an earlier study that showed only $41.7 \%$ of patients receiving a biliary Bedside US were discharged home. ${ }^{35}$ Unlike our study, however, this prior study was performed at a tertiary care hospital, which provided higher level of specialized medical care. Nonetheless, the expected likelihood of patients being discharged home seen in the prior study more closely reflected the percentages seen in patients receiving a Tech US or NO US (40.9\% to 55\%) within our study. ${ }^{35}$ 
Table 2. Vital and lab work upon presentation

\begin{tabular}{|c|c|c|c|c|}
\hline & $\begin{array}{l}\text { No Ultrasound } \\
(\mathrm{N}=235)\end{array}$ & $\begin{array}{l}\text { Formal Ultrasound } \\
\qquad(\mathrm{N}=182)\end{array}$ & $\begin{array}{l}\text { Bedside Ultrasound } \\
\qquad(\mathrm{N}=32)\end{array}$ & $\begin{array}{c}\mathrm{p}- \\
\text { value }\end{array}$ \\
\hline \multicolumn{5}{|l|}{ Initial Vitals } \\
\hline Temperature (Celsius) & & & & 0.14 \\
\hline Mean+/- SD (median) & $36.8+/-0.4(36.8)$ & $36.8+/-0.4(36.8)$ & $36.7+/-0.2(36.7)$ & \\
\hline Min to $\max$ & 36.1 to 39.6 & 36.1 to 39.4 & 36.3 to 37.1 & \\
\hline Heart Rate & & & & 0.13 \\
\hline Mean+/-SD (median) & $82+/-18(79)$ & $79+/-15(77)$ & $80+/-17(80)$ & \\
\hline Min to $\max$ & 49 to 163 & 51 to 128 & 48 to 136 & \\
\hline Systolic Blood Pressure & & & & 0.59 \\
\hline Mean+/- SD (median) & $134+/-21(134)$ & $132+/-20(134)$ & $132+/-21(134)$ & \\
\hline Min to max & 91 to 201 & 87 to 202 & 83 to 183 & \\
\hline Diastolic Blood Pressure & & & & 0.88 \\
\hline Mean+/-SD (median) & $77+/-15(76)$ & $77+/-13(78)$ & $79+/-13(77)$ & \\
\hline Min to max & 18 to 125 & 45 to 113 & 61 to 114 & \\
\hline $\begin{array}{l}\text { Respiratory rate (breaths/ } \\
\text { min) }\end{array}$ & & & & 0.11 \\
\hline Mean+/- SD (median) & $19+/-5(18)$ & $19+/-4(18)$ & $18+/-2(18)$ & \\
\hline Min to $\max$ & 12 to 78 & 12 to 61 & 14 to 28 & \\
\hline \multicolumn{5}{|l|}{ Labs } \\
\hline WBC & & & & 0.13 \\
\hline Mean+/- SD & $10.6+/-4.1$ & $10.2+/-4.1$ & $9.1+/-3.0$ & \\
\hline Median $\left(25^{\text {th }}, 75^{\text {th }}\right)$ & $9.8(7.8,12.4)$ & $9.7(7.1,12.6)$ & $8.7(6.7,10.9)$ & \\
\hline Min to max & 3.4 to 33.8 & 3.3 to 25.1 & 2.5 to 16.9 & \\
\hline Hemoglobin & & & & 0.06 \\
\hline Mean+/-SD & $13.4+/-1.6$ & $13.5+/-1.7$ & $13.0+/-1.6$ & \\
\hline Median (25th, $\left.75^{\text {th }}\right)$ & $13.3(12.4,14.3)$ & $13.6(12.5,14.7)$ & $12.9(11.7,13.9)$ & \\
\hline Min to $\max$ & 9.6 to 18.6 & 4.8 to 16.9 & 10 to 16.6 & \\
\hline BUN & & & & 0.31 \\
\hline Median $\left(25^{\text {th }}, 75^{\text {th }}\right)$ & $12(9,18)$ & $12(9,15)$ & $12(9,16)$ & \\
\hline Min to $\max$ & 3 to 95.5 & 4 to 36 & 5 to 22 & \\
\hline Creatinine & & & & 0.95 \\
\hline Median (25 th, $\left.75^{\text {th }}\right)$ & $0.79(0.69,0.97)$ & $0.80(0.69,0.96)$ & $0.81(0.71,0.99)$ & \\
\hline Min to max & 0.44 to 3.46 & 0.50 to 7.20 & 0.49 to 1.68 & \\
\hline Total Bilirubin & & & & 0.016 \\
\hline Median ( $\left.25^{\text {th }}, 75^{\text {th }}\right)$ & $0.5(0.3,1.2)$ & $0.5(0.3,1.1)$ & $0.3(0.2,0.5)$ & \\
\hline Min to $\max$ & 0.1 to 28.5 & 0.1 to 20.5 & 0.1 to 5.5 & \\
\hline AST & & & & 0.42 \\
\hline Median (25 th, $\left.75^{\text {th }}\right)$ & $27(18,93)$ & $28(19,101)$ & $25(19,46)$ & \\
\hline Min to $\max$ & 2 to 2055 & 10 to 2076 & 12 to 467 & \\
\hline ALT & & & & 0.052 \\
\hline Median $\left(25^{\text {th }}, 75^{\text {th }}\right)$ & $27(17,94)$ & $31(18,90)$ & $22(13,31)$ & \\
\hline Min to max & 5 to 2671 & 7 to 1450 & 7 to 230 & \\
\hline Alk Phos & & & & 0.31 \\
\hline Median ( $\left.25^{\text {th }}, 75^{\text {th }}\right)$ & $90(67,144)$ & $85(70,130)$ & $75(63,113)$ & \\
\hline Min to max & 37 to 733 & 35 to 1601 & 40 to 768 & \\
\hline Lipase & & & & 0.59 \\
\hline Median (25 th, $\left.75^{\text {th }}\right)$ & $32(23,49)$ & $32(21,48)$ & $29(24,40)$ & \\
\hline
\end{tabular}




\begin{tabular}{|c|c|c|c|c|}
\hline & $\begin{array}{c}\text { No Ultrasound } \\
(\mathbf{N}=\mathbf{2 3 5})\end{array}$ & $\begin{array}{c}\text { Formal Ultrasound } \\
(\mathbf{N}=182)\end{array}$ & $\begin{array}{c}\text { Bedside Ultrasound } \\
(\mathbf{N}=\mathbf{3 2})\end{array}$ & $\begin{array}{c}\mathrm{p}- \\
\text { value }\end{array}$ \\
\hline Min to max & 6 to 3000 & 10 to 30000 & 12 to 101 & \\
\hline
\end{tabular}

$\mathrm{SD}=$ standard deviation

$\mathrm{WBC}=$ white blood cell

BUN $=$ blood urea nitrogen

AST $=$ aspartate aminotransferase

$\mathrm{ALT}=$ alanine aminotransferase

Alk Phos = alkaline phosphatase

Statistically significant values appear in bold font.

Table 3: Emergency Department (ED) Imaging, Length of Stay and Disposition

\begin{tabular}{|c|c|c|c|c|}
\hline & $\begin{array}{l}\text { No Ultrasound } \\
(\mathrm{N}=235)\end{array}$ & $\begin{array}{l}\text { Formal Ultrasound } \\
\qquad(\mathrm{N}=182)\end{array}$ & $\begin{array}{l}\text { Bedside Ultrasound } \\
\qquad(\mathrm{N}=32)\end{array}$ & $p$-value \\
\hline CT imaging & 145/235 (61.7\%) & 53/182 (29.1\%) & 5/32 (15.6\%) & $<0.0001$ \\
\hline $\begin{array}{l}\text { ED Length of Stay } \\
\text { (hours) }\end{array}$ & & & & $<0.0001$ \\
\hline Median $\left(25^{\text {th }}, 75^{\text {th }}\right)$ & $4.5(3.0,6.0)$ & $5.0(4.0,7.0)$ & $3.0(2.0,4.3)$ & \\
\hline Min to max & 1 to 11 & 2 to 15.5 & 1 to 8 & \\
\hline ED Disposition & & & & 0.0006 \\
\hline Home & $96(40.9 \%)$ & $100(55.0 \%)$ & $26(81.3 \%)$ & \\
\hline Observation & $10(4.3 \%)$ & $7(3.9 \%)$ & $1(3.1 \%)$ & \\
\hline Hospital admission & $116(49.4 \%)$ & $64(35.2 \%)$ & $4(12.5 \%)$ & \\
\hline Transfer & 13 (5.5\%) & 11 (6.0\%) & 1 (3.1\%) & \\
\hline
\end{tabular}

Despite the literature demonstrating the utility of a Bedside US, the use of this modality remains restricted. ${ }^{44}$ The arguments against Bedside US use (e g., importance of obtaining an isolated common bile duct dilation measurement, inferiority to an accredited radiography US or limitation with non-fasting patients) have been disproven. ${ }^{44,45}$ However, in our study, only $7.2 \%$ of our patients received a Bedside US.

Based on review of the literature, we recommend continued incorporation of Bedside US teachings to residents and direct studies comparing the Bedside US to Tech US in complicated biliary diseases to improve confidence of Bedside US diagnosis and use. ${ }^{26,33}$

In 2016, the American College of Emergency Physicians has issued a statement stating that Bedside US techniques in the ED should be a fundamental element of Emergency Medicine training. Furthermore, the Accreditation Council for Graduate Medical Education (ACGME) mandated procedural competency for all Emergency Medicine residents. ${ }^{46}$ Although biliary is listed as one of the core ED ultrasound applications, there is still no uniform standardized implemented emergency medicine Bedside US curriculum. ${ }^{47,48}$

As previously mentioned, additional perceived barriers that ultimately influence surgical management include acceptance of the reliability of a Bedside US within the surgical community to influence operative decisions for cholelithiasis and cholecystitis. ${ }^{28,31}$ A recent 2020 survey evaluating Canadian general surgeons' perceptions of a biliary Bedside US revealed that most surgeons believed the sensitivity of Bedside US to be much lower for cholelithiasis and cholecystitis than actual literature results. ${ }^{49}$

Results from a similar study mirrored the lack of confidence by general surgery and other consultants on trusting Bedside US performed by emergency medicine physicians. ${ }^{50}$ Meanwhile, there remains a paucity of studies in which the Bedside US was the sole modality of imaging for diagnosing biliary disease resulting in operative management. ${ }^{27}$

Several limitations of our study include our retrospective single-institution study design that may not be representative of the national use of Bedside US. Our analyses were also limited by the convenience of sample of patients presenting with symptoms of right upper quadrant or epigastric abdominal pain, nausea, vomiting and/or jaundice.

\section{CONCLUSIONS}

Based on these study results, Bedside US may be a usable tool to facilitate ED evaluation of gallbladder diseases in more resource-limited community healthcare settings. However, the current practice remains to use Bedside US in a relatively selective gallbladder disease population. Further studies are needed to systematically evaluate surgeon attitudes and tailor educational interventions to address such concerns within the surgical community.

\section{FUNDING}

The authors report no external funding source for this 
study.

The authors declare no conflict of interest.
Submitted: September 15, 2020 EDT, Accepted: November 30, 2020 EDT 


\section{REFERENCES}

1. Russo MW, Wei JT, Thiny MT, et al. Digestive and liver diseases statistics, 2004. Gastroenterol. 2004;126(5):1448-1453. doi:10.1053/i.gastro.2004.0 $\underline{1.025}$

2. Marschall H-U, Einarsson C. Gallstone disease. J Intern Med. 2007;261(6):529-542. doi:10.1111/j.136 5-2796.2007.01783.x

3. Portincasa P, Moschetta A, Palasciano G. Cholesterol gallstone disease. The Lancet. 2006;368(9531):230-239. doi:10.1016/s0140-6736(0 6)69044-2

4. Shaffer EA, Small DM. Biliary lipid secretion in cholesterol gallstone disease. The effect of cholecystectomy and obesity. J Clin Invest. 1977;59(5):828-840.

5. Carey MC. Pathogenesis of gallstones. Recenti Prog Med. 1992;83(7-8):379-391.

6. Shabanzadeh DM, Sørensen LT, Jørgensen T. Determinants for gallstone formation - a new data cohort study and a systematic review with metaanalysis. Scand J Gastroenterol. 2016;51(10):1239-1248. doi:10.1080/00365521.2016.1 $\underline{182583}$

7. Bonfrate L, Wang DQ-H, Garruti G, Portincasa P. Obesity and the risk and prognosis of gallstone disease and pancreatitis. Pract Res Clin Gastroenterol. 2014;28(4):623-635. doi:10.1016/j.bpg.2014.07.013

8. Lammert F, Gurusamy K, Ko CW, et al. Gallstones. Nat Rev Dis Primers. 2016;2(1):1-17. doi:10.1038/nrd p.2016.24

9. Yu MH, Kim YJ, Park HS, Jung SI. Benign gallbladder diseases: Imaging techniques and tips for differentiating with malignant gallbladder diseases. World J Gastroenterol. 2020;26(22):2967-2986. doi:1 0.3748/wjg.v26.i22.2967

10. Guzmán HM, Sepúlveda M, Rosso N, San Martin A, Guzmán F, Guzmán HC. Incidence and risk factors for cholelithiasis after bariatric surgery. Obes Surg. 2019;29(7):2110-2114. doi:10.1007/s11695-019-0376 $\underline{0-4}$

11. Pak M, Lindseth G. Risk factors for cholelithiasis. Gastroenterol Nurs. 2016;39(4):297-309. doi:10.1097/s ga.0000000000000235
12. Cuevas A, Miquel JF, Reyes MS, Zanlungo S, Nervi F. Diet as a risk factor for cholesterol gallstone disease. J Am Coll Nutr. 2004;23(3):187-196. doi:10.10 $\underline{80 / 07315724.2004 .10719360}$

13. Shaffer EA. Epidemiology and risk factors for gallstone disease: Has the paradigm changed in the 21st century? Curr Gastroenterol Rep. 2005;7(2):132-140. doi:10.1007/s11894-005-0051-8

14. Internal Clinical Guidelines Team (UK). Gallstone Disease: Diagnosis and Management of Cholelithiasis, Cholecystitis and Choledocholithiasis. London: National Institute for Health and Care Excellence (UK); 2014. https://www.ncbi.nlm.nih.gov/books/NBK 327525/.

15. Alemi F, Seiser N, Ayloo S. Gallstone disease: Cholecystitis, mirizzi syndrome, bouveret syndrome, gallstone Ileus. Surg Clin North Am. 2019;99(2):231-244. doi:10.1016/j.suc.2018.12.006

16. Sakorafas GH, Milingos D, Peros G. Asymptomatic cholelithiasis: Is cholecystectomy really needed? A critical reappraisal 15 years after the introduction of laparoscopic cholecystectomy. Dig Dis Sci. 2007;52(5):1313-1325. doi:10.1007/s10620-006-910 $\underline{7-3}$

17. Duncan CB, Riall TS. Evidence-based current surgical practice: Calculous gallbladder disease. $J$ Gastrointest Surg. 2012;16(11):2011-2025. doi:10.100 7/s11605-012-2024-1

18. American College of Radiology. ACR appropriateness criteria ${ }^{\circledR}$ : Right upper quadrant pain. 2018. https://acsearch.acr.org/docs/69474/Narrative/.

19. Moore CL, Molina AA, Lin H. Ultrasonography in community emergency departments in the united states: Access to ultrasonography performed by consultants and status of emergency physicianperformed ultrasonography. Ann Emerg Med. 2006;47(2):147-153. doi:10.1016/j.annemergmed.200 $\underline{5.08 .023}$

20. Buerger AM, Clark KR. Point-of-care ultrasound: A trend in health care. Radiol Technol. 2017;89(2):127-138.

21. Abu-Zidan FM, Cevik AA. Diagnostic point-ofcare ultrasound (POCUS) for gastrointestinal pathology: State of the art from basics to advanced. World J Emerg Surg. 2018;13(1):47. doi:10.1186/s1301 7-018-0209-y 
22. Gleeson T, Blehar D. Point-of-care ultrasound in trauma. Semin Ultrasound CT MR. 2018;39(4):374-383. doi:10.1053/i.sult.2018.03.007

23. Campbell SJ, Bechara R, Islam S. Point-of-care ultrasound in the intensive care unit. Clin Chest Med. 2018;39(1):79-97. doi:10.1016/j.ccm.2017.11.005

24. Shrestha GS, Weeratunga D, Baker K. Point-ofcare lung ultrasound in critically ill patients. Rev Recent Clin Trials. 2018;13(1):15-26. doi:10.2174/1574 $\underline{887112666170911125750}$

25. Blanco P, Volpicelli G. Common pitfalls in pointof-care ultrasound: A practical guide for emergency and critical care physicians. Crit Ultrasound J. 2016;8(1):15. doi:10.1186/s13089-016-0052-X

26. Blaivas M, Harwood RA, Lambert MJ. Decreasing length of stay with emergency ultrasound examination of the gallbladder. Acad Emerg Med. 1999;6(10):1020-1023. doi:10.1111/j.1553-2712.199 9.tb01186.x

27. Scruggs W, Fox JC, Potts B, Zlidenny A, McDonough J, Anderson CL, et al. Accuracy of ED bedside ultrasound for identification of gallstones: Retrospective analysis of 575 studies. West J Emerg Med. 2008;9(2):129.

28. Reens D, Podgorski B. Hemorrhagic cholecystitis: A case of expedited diagnosis by point-of-Care ultrasound in the emergency department. J Emerg Med. 2019;57(1):74-76. doi:10.1016/j.jemermed.201 9.03.010

29. Lim N, McCabe A, Cronin J. Use of emergency department point-of-care ultrasound in a case of cholecystitis. BMJ Case Rep. November 2017:bcr2017220872. doi:10.1136/bcr-2017-220872

30. Damman J, Doniger SJ, Atigapramoj N. Neonatal gallstones serendipitously discovered by point-ofcare ultrasound in the pediatric emergency department. Pediatr Emerg Care. 2016;32(10):734-735. doi:10.1097/pec.000000000000 $\underline{0622}$

31. Tsung JW, Raio CC, Ramirez-Schrempp D, Blaivas M. Point-of-care ultrasound diagnosis of pediatric cholecystitis in the ED. Am J Emerg Med. 2010;28(3):338-342. doi:10.1016/i.ajem.2008.12.003

32. Summers SM, Scruggs W, Menchine MD, et al. A prospective evaluation of emergency department bedside ultrasonography for the detection of acute cholecystitis. Ann Emerg Med. 2010;56(2):114-122. do i:10.1016/i.annemergmed.2010.01.014
33. Gaszynski R, Lim C, Chan DL, et al. Surgical ultrasonography at the bedside: A comparison of surgical trainees with trained sonographers for symptomatic cholelithiasis - a first Australian experience. ANZ J Surg. 2019;89(5):492-496. doi:10.11 11/ans.14928

34. Wexler BB, Panebianco NL. The effervescent gallbladder: An emergency medicine bedside ultrasound diagnosis of emphysematous cholecystitis. Cureus. 2017;9(7):e1520. doi:10.7759/cu reus. 1520

35. Hilsden R, Leeper R, Koichopolos J, et al. Point-ofcare biliary ultrasound in the emergency department (BUSED): Implications for surgical referral and emergency department wait times. Trauma Surg Acute Care Open. 2018;3(1):e000164. doi:10.1136/tsaco-201 8-000164

36. Zenobii MF, Accogli E, Domanico A, Arienti V. Update on bedside ultrasound (US) diagnosis of acute cholecystitis (AC). Intern Emerg Med. 2016;11(2):261-264. doi:10.1007/s11739-015-1342-1

37. ICD - ICD-9-CM - International Classification of Diseases, Ninth Revision, Clinical Modification. Centers for Disease Control and Prevention, Centers for Disease Control and Prevention; 2015. https://www.c dc.gov/nchs/icd/icd $9 \mathrm{~cm} . h t m$.

38. ICD - ICD-10-CM - International Classification of Diseases, Tenth Revision, Clinical Modification. Centers for Disease Control and Prevention, Centers for Disease Control and Prevention; 2020. https://www.c dc.gov/nchs/icd/icd $10 \mathrm{~cm} . h \mathrm{tm}$.

39. Hospital \& Health Systems. Cerner. 2020. http://w ww.cerner.com/solutions/health-systems.

40. Lovric M, ed. Fisher Exact Test. In: International Encyclopedia of Statistical Science. Berlin, Heidelberg: Springer; 2011

41. Kruskal-Wallis Test. The Concise Encyclopedia of Statistics. New York, NY: Springer; 2008.

42. Henwood PC, Mackenzie DC, Rempell JS, et al. A practical guide to self-sustaining point-of-care ultrasound education programs in resource-limited settings. Ann Emerg Med. 2014;64(3):277-285.e2. do i:10.1016/j.annemergmed.2014.04.013

43. Pines JM. Profiles in patient safety: Confirmation bias in emergency medicine. Acad Emerg Med. 2006;13(1):90-94. doi:10.1197/i.aem.2005.07.028

44. Lahham S, Becker BA, Gari A, et al. Utility of common bile duct measurement in ED point of care ultrasound: A prospective study. Am J Emerg Med. 2018;36(6):962-966. doi:10.1016/i.ajem.2017.10.064 
45. Breyer MJ, Giordano M, Tinjum B, et al. Emergency medicine resident performed bedside ultrasonography of the gallbladder in non-fasted healthy volunteers. J Emerg Med. 2010;39(1):65-69. do i:10.1016/j.jemermed.2008.10.002

46. Ultrasound Guidelines: Emergency, Point-of -Care, and Clinical Ultrasound Guidelines in Medicine. ACEP // Ultrasound Guidelines: Emergency, Point-of -Care, and Clinical Ultrasound Guidelines in Medicine. 2016; American College of Emergency Physicians; 2016. htt ps://www.acep.org/globalassets/new-pdfs/policy-stat ements/ultrasound-guidelines---emergency-point-o f-care-and-clinical-ultrasound-guidelines-in-medicin e.pdf.

47. Sena A, Alerhand S, Lamba S. Milestone Approach to designing a point-of-care ultrasound curriculum for transition-to-residency programs in the United States. Teaching and Learning in Medicine. October 2020:1-12. doi:10.1080/10401334.2020.1814296
48. Boulger C, Adams DZ, Hughes D, Bahner DP, King A. Longitudinal ultrasound education track curriculum implemented within an emergency medicine residency program. J Ultrasound Med. 2017;36(6):1245-1250. doi:10.7863/ultra.16.08005

49. Koichopolos J, Hilsden R, Myslik F, Thompson D, Vandelinde J, Leeper R. Surgeon attitudes toward point of care ultrasound for biliary disease: A nationwide Canadian survey. Can J Surg. 2020;63(1):E9-E12. doi:10.1503/cjs.010218

50. Hansen W, Mitchell CE, Bhattarai B, Ayutyanont N, Stowell JR. Perception of point-of-care ultrasound performed by emergency medicine physicians. J Clin Ultrasound. 2017;45(7):408-415. doi:10.1002/jcu.2244 $\underline{3}$ 